\title{
Popular Reactions to Coordination Problems under External Threats
}

\author{
SANDRA LEÓN* \\ AmUitz GARMENDia MAdARIAGA ${ }^{\ddagger}$
}

February 19, 2021

Working Paper (Version 4)

\begin{abstract}
Exogenous threats pose a formidable challenge to federations, as they compel governments at all levels to cooperate to prevent a collective risk. As the vertical fragmentation of powers complicates a coordinated response, we here argue that the central government becomes the focal point of the solution. In search of a more effective response against the threat, citizens coordinate their preferences around the centralization of authority boundaries in the federation. We test this argument first using an on-line survey experiment in Spain, a country where the threat caused by COVID-19 has operated on top of non-negligible centrifugal threats. The empirical analyses show that, in the context of the pandemic, exposure to vertical coordination failures prompt citizens to support a centralized redrawing of authority boundaries, though this effect is importantly conditioned by respondents' partisanship and territorial preferences. We repeat the same experiment in a comparative sample of 12 federations, quasi-federations and decentralized unitary countries. Our findings suggest that external shocks may represent turning points for the stability of federations, as citizens' demands for a response might encounter elite level strategic adjustments of authority.
\end{abstract}

\footnotetext{
*Associate Professor, Universidad Carlos III de Madrid (sandra.leon@uc3m.es)

† Assistant Professor, Universidad Carlos III de Madrid (amuitz.garmendia@uc3m.es)

${ }^{\ddagger}$ This research is part of the Project Federalism in Polarized Times, 2019-00029-001, funded by the regional government of Madrid through the Senior Talento Research Program.
} 
"The most important forces of a political, or psychological, order which serve as efficient agents in the creation of federation are fear, a calculated expectation of advantage, and a response to some unifying ideal or myth. Of these three, the most important motivation is probably fear. Fear may develop from direct attempts at intimidation, or from a sustained and profound feeling of insecurity."

- Maddox (1941, 1122)

\section{INTRODUCTION}

The outbreak of the COVID-19 in 2020 shook federal governance around the world. ${ }^{1}$ Some governments temporarily chose to re-centralize certain powers, such as Switzerland or Spain, and in most federations, intergovernmental conflict on when and how to emerge after the shutdowns ensued. In the midst of the crisis, the President of the United States, Donald Trump, claimed "total authority over state decisions" in the pandemic, ${ }^{2}$ whereas in Brazil, state governors rose up against Jair Bolsonaro's inactivity by imposing their own measures to close businesses, schools and public spaces. ${ }^{3}$ Even in the quintessential model of cooperative federalism, the German chancellor Angela Merkel warned early on in the pandemic against a "passing the buck" dynamic: "Federalism is not there so people can push away responsibility. It is there so that everyone takes responsibility in their area." Coronavirus represents the greatest threat to states since the World War II and the most formidable coordination challenge for federal structures. Yet threat lies at the core of the federal momentum, as fear has been the most powerful driving force of federalism.

Federal entities have emerged out of different types of perils, but all of them have prompted political elites to consider that giving authority up, either upwards (to a centralized government) or downwards (to new regional units) was less costly than the realization of the specific threat. For instance, in coming-together federations, the centralization of authority into a federal union is explained by the existence of an external military (Riker, 1964) or economic (Dikshit, 1971; Garrett and Rodden, 2006) threat; whereas in holding-together federations (Stepan, 1999), the devolution of powers to subcentral units is the result of internal ethno-regional heterogeneity (Birch, 1966) or even ethnic conflict or secessionist challenges (Amoretti and Bermeo, 2004).

\footnotetext{
${ }^{1}$ See OECD's "The Territorial Impact of COVID-19: Managing the Crisis across levels of Government"

${ }^{2}$ POLITICO, 2020/04/13: "Trump claims total authority over state decisions"

${ }^{3}$ The Guardian, 2020/04/01: "Bolsonaro ignored by state governors"
} 
Ideally, federal contracts aim to be 'robust' Bednar (2008); that is, to show a balance between a federal government powerful enough to ensure redistribution and macroeconomic stability but not too powerful to encroach upon subcentral authority, and a set of subcentral units with sufficient authority to accrue the benefits of decentralized governance but not too independent to free-ride on the collective goods (Riker, 1964). However, once established, federal contracts do not remain stable over time. Centripetal or centrifugal dynamics may develop, challenging the equilibrium in which the stability of a federation is grounded. Changes in the distribution of powers within federations have been mostly accounted for in the literature as the result of political dynamics where party systems, coordination among elites and electoral strategies play a fundamental role (Filippov, Ordeshook and Shvetsova, 2004). Yet the study of the impact of external shocks either of a short-term (economic crisis) or long-term nature (globalization) has lagged behind (Beramendi and Rogers, 2019; Beramendi and Stegmueller, 2020; Garrett and Rodden, 2006; Jurado and León, 2020). The literature also exhibits a bias towards elite bargaining and party competition when accounting for adjustment in the distribution of authority between central and state governments, whereas, with the exception of secessionist popular movements (Muñoz and Tormos, 2020), the role of public preferences and demands for changes in authority boundaries have been overlooked.

This paper purports to fill this literature gap by providing a better understanding of the impact of an external shock - the sanitary threat caused by the COVID-19 - upon citizens' preferences towards vertical distribution of authority in federations. We argue that the pandemic pose a formidable coordination challenge in federations. By signaling cooperation as a crucial mechanism to prevent collective risk, threats turn intergovernmental relations into a salient issue for citizens. As the vertical fragmentation of powers complicates a coordinated response, the central government becomes the focal point of the solution. In search of a more effective response against the threat, individuals will demand a stronger role of the central government, that is, an entity that is organizationally able to coordinate smaller autonomous jurisdictions to avoid "anarchy" (Madison, Federalist Papers n. 51). We also expect this centralizing drift to be moderated by the existing dimensions of political competition in a federation.

We explore this question in one of the most affected countries during this crisis: Spain. In this quasi- 
federation, ${ }^{4}$ the external threat caused by the pandemic has operated on top of the internal threats posed by the various regional level incumbent pro-independence parties, for instance, in the Basque Country and Catalonia. In this sense, Spain represents a least likely case scenario for our theoretical argument, as the potential centralizing drift associated to an external shock might be moderated by internal threats that push the distribution of authority in the opposite direction. We also test for the existence of the explained effect in a comparative sample of institutionally diverse countries. Drawing on several online survey experiment analyses, our paper shows that exposure to vertical coordination failures in the context of a particularly salient external threat prompts citizens to support a centralized redrawing of authority boundaries. Moreover, it demonstrates that this effect survives in time, as long as the threat continues to be salient.

Accordingly, our results speak to what probably represents the most important theoretical question in the area of federal studies: federal stability and its main drivers. One of the most important challenges in this sense is a poor match between the distribution of authority in a federation and its needs and potential (Bednar, 2008); a shortcoming that might become particularly evident when the federation is exposed to an external threat. The distribution of authority might adapt after the shock, but little is known about whether these changes are prompted by (or aligned with) a change in citizens' preferences over authority boundaries. In fact, we demonstrate that the mentioned average treatment effect in our experiment is significantly conditioned by respondents' political preferences regarding ideology and their overall territorial preferences. This paper contributes to shed some light on this question by theorizing on popular reactions to external threats in federations and showing that shocks open an opportunity for a centralizing drift. Our findings suggest that shocks may represent turning points for the stability of a federation and, ultimately, a test for its safeguards if citizens demands for a redrawing of authority are followed by opportunistic adjustments of authority.

\footnotetext{
${ }^{4}$ According to (Bednar, 2008, 18), a country is quasi-federal if it meets two of the following three structural criteria: "1. Geopolitical Division: The territory is divided into mutually exclusive units, and their existence, is constitutionally recognized and may not be unilaterally abolished. 2. Independence: The state and national governments have independent bases of authority. In general, this independence is established constitutionally through electoral independence, where each government is held accountable to its constituents, although nondemocratic forms of independence may be available. 3. Direct Governance: Authority is shared between the state and the national governments: each governs its citizens directly, so that each citizen is governed by at least two authorities. Each level of government is sovereign in at least one policy realm. This policy sovereignty is constitutionally declared." Spain fails to meet requirement 1 , since the structure of its regional geopolitical divisions are absent of the constitutional text.
} 


\section{Exogenous Threats and Federal Centralization}

External threats have often been deemed as one of the most "efficient agents in the creation of a federation" (Maddox, 1941, 1122). According to Riker (1964, 12), two necessary conditions have always been present in all the empirical cases of federal bargains since 1786, including the United States: 1) the expansion condition and 2) the military condition. The first one refers to those politicians offering the federal bargain and speaks to their willingness to exchange concessions to constituent units for territorial expansion, "usually either to meet an external military or diplomatic threat or to prepare for military or diplomatic aggression and aggrandizement." The second one characterizes the behavior of those politicians accepting the bargain; that is, their willingness to "give up some independence for the sake of union and they do so because of some external military-diplomatic threat or opportunity." Dikshit $(1971,189)$ questions Riker's military interpretation of federal constitutions by suggesting that rather than necessary, the mentioned predispositions are absent in the origin of modern examples of centralized federations. Yet, he does not deny the power of external challenges in the origin of federal bargains. On the contrary, he praises modern centralized federations as complex structures born to deliver centralized national planning in the new global context of large-scale industrialized economies.

The First Generation of Fiscal Federalism (FGFF) developed this idea thoroughly: federalism was thought to combine the different advantages which result "from the magnitude and the littleness of nations" (Tocqueville, 1835). Oates' (1972) 'Decentralization Theorem' is based on two assumptions (Oates, 1999, 1121): on the one hand, decentralized levels of government have a unique capacity to tailor the provision of goods and services to the particular preferences and circumstances of their constituencies; on the other hand, central governments have a basic macroeconomic stabilization responsibility, which, in the presence of highly open economies, implies redistributing income to avoid horizontal fiscal imbalances, controlling monetary and exchange rate prerogatives and their fiscal stimuli, and providing those public goods, like national defense, that become efficient under the economies of scale or greater coordination. Public Choice scholars re-examined the normative conception of governments as 'benevolent planners' underlying FGFF theories. Authors under this approach emphasized instead that governments had a natural tendency towards excess, capture and overspending and correspondingly, supported decentralized decision-making in federations, as a small jurisdiction- 
based competition for fiscally efficient policy delivery (Brennan and Buchanan, 1980). However, none of these critics challenge the potential stabilizing power of centralized federations when facing external threats.

Quite the contrary, there seems to be an agreement on the fact that globalization has made countries more vulnerable to external shocks and thus that macroeconomic stabilization and interregional risk sharing via the enhancement of central government's fiscal authority continue to be the most suitable choices for federations under the mentioned circumstances (Garrett and Rodden, 2006, 278). For instance, a recent study in 21 OECD countries finds that, in the years following the Great Recession, fiscally decentralized nations, given their weaker redistributive mechanisms, saw increased interpersonal inequality and lower redistribution, while preserving market-driven declines in high productivity areas that increased regional convergence (Beramendi and Rogers, 2019). Probably as a way of preemptively tackling this empirical regularity, in the aftermath of the Great Recession, several economically advanced federations and quasi-federations went through reforms that led to the establishment of limits to subnational units' debt $^{5}$, the recentralization of certain policy areas ${ }^{6}$ or the rationalization of the number of jurisdictions in a certain territory ${ }^{7}$. Moreover, the literature on the breakup of nations (Alesina and Spolaore, 1997; Alesina, Spolaore and Wacziarg, 2000) has established that growing international trade provides regions or constitutive units with a substitute for the scale benefits of being part of a large country, lowering their exit costs and thus increasing their likelihood of secession. This potential effect seems particularly challenging for those federations that are subject to large centrifugal forces (Bakke and Wibbels, 2006; Kymlicka, 2005; Sambanis and Milanovic, 2014). In fact, as a way of buying out powerful regions against their exit options (de Figueiredo Jr and Weingast, 2005), another recent study shows that there is a strong and positive empirical relationship between economic globalization and decentralization in countries with a high presence of regionalist parties (Jurado and León, 2020).

Birch (1966) was the first to present internal threats as equally relevant necessary conditions in the origin of some federal bargains. He identified instances in which the divisive characteristics of

\footnotetext{
${ }^{5}$ In the summer of 2011, the two major political parties in Spain (PSOE and PP) agreed on an express reform of the Constitution that limited de jure Spanish debt, by linking it to its GDP, and that had direct consequences for the borrowing autonomy of its regions.

${ }^{6}$ See Beramendi and Stegmueller (2020) for more on this issue.

${ }^{7}$ For instance, while France went through a territorial transformation that reduced the number of regions from 22 to 13 in 2016, a similar reform was rejected in Renzi's Constitutional Reform Referendum that same year in Italy.
} 
the political and ethno-religious geographic makeup of a territory make federations alternative institutional choices to unions (Amoretti and Bermeo, 2004; Ziblatt, 2006). As Stepan (1999) emphasizes, top-down or holding-together federations include much of the twentieth century trend towards decentralization of authority worldwide. These federations or quasi-federations (Bednar, 2008) are different in terms of who holds the agenda-setting power. In bottom-up or coming-together federations, "the constituent states design the federation and will attempt to choose institutions that capture the rents for themselves", whereas, in top-down or holding-together federalism, "the central government controls the design and will bias institutions in its favor" (de Figueiredo Jr and Weingast, 2005, 128). Interestingly, the latter federations coexist with both types of potential threats, which represent centripetal and centrifugal sources of stress for the system, resulting in a more unstable federal contract.

\section{The Popular Roots of Federations}

As it appears, most of the academic research on the origin and evolution of federal bargains is largely elite focused and has revolved around federal institutional design, change and derived outcomes. To the extent to which elites are partisan in democracies, federal institutions alone do not have a significant impact on the stability of the federal bargain, and it is the structure of the political parties and their interests the ones shaping the statu quo (Filippov, Ordeshook and Shvetsova, 2004; Riker, 1964). Consequently, the Second Generation of Fiscal Federalism (SGFF) has taken more seriously than previous approaches the role of preference aggregation through voting and lobbying in accounting for the stability and change in federations (Amat and Falcó-Gimeno, 2014; Beramendi, 2012; Dixit and Londregan, 1996; Gibson, Calvo and Falleti, 2004; Inman and Rubinfeld, 1997; Oates, 2005; Qian and Weingast, 1997; Rodden, 2006; Rodden and Wibbels, 2002; Wibbels, 2005).

Still, studies on the role of public's preferred vertical distribution of authority in the stability and change of federations are scarce in the literature (Kincaid and Cole, 2011, 2015) and they have been typically indirectly approximated through the analysis of party strategies in a second (territorial) dimension of electoral competition (Toubeau and Wagner, 2015) ${ }^{8}$, particularly in countries where this

\footnotetext{
${ }^{8}$ Toubeau and Wagner's (2015) findings suggest that parties on the economic right are more supportive of decentralization than parties on the economic left, while culturally liberal parties favor decentralization more than culturally conservative parties, although contextual factors such as interregional economic inequality, the degree of regional self-rule, or the presence of regionalist parties, all shape the position of these parties when determining the territorial distribution of power.
} 
second dimension is relatively salient (Alonso, 2012; Dandoy and Schakel, 2013; Elias, Szöcsik and Zuber, 2015) ${ }^{9}$. Federations with a salient territorial dimension have electorates that show an active and politized position about the statu quo form of the state and the potential alternative vertical distributions of authority (Pardos-Prado and Sagarzazu, 2019).

The scant literature on citizens' attitudes towards the federal bargain contrasts with Madison's concerns on public approval. In Federalist 46, he wondered which level of government "will have the advantage with regard to the predilection and support of the people". Wheare $(1946,36)$ also emphasized that federal polity's constituent political communities must have "the capacity as well as the desire to form an independent general government and to form independent regional governments". More generally, a large part of the existing contemporary theories on the promise of federalism are democratic, and thus rest in the assumption of politics representing citizens' preferences. According to Bednar, the role of citizens' attitudes towards federal and state authority boundaries should be especially relevant when federations experience shifts in the distribution of authority, as they often do. Should centripetal or centrifugal dynamics ensue in a federation, we should expect popular support to play a significant role in accounting for the changing nature of the federal bargain, either as a specific driver of the reforms, or as a safeguard preventing authority adjustments to result in opportunistic transgressions $(2008,107)$.

Then, exploring the role of citizens' attitudes towards the federal bargain becomes particularly intriguing when federations are exposed to a threat. ${ }^{10}$ Even the most resilient federation might not be immune to an external shock; the latter may uncover flaws in federal design or a mismatch between the existing distribution of authority and the federation's needs. Federations may react by adapting authority distribution, but tackling the challenges posed by an external threat should count on the popular awareness of the threat, as well as on the awareness of the benefits of redrawing authority boundaries to better respond to the threat. Yet little is known on popular reactions to these threats. We ignore whether federal adjustment is prompted by - or at least aligned with - a change in citizens'

\footnotetext{
${ }^{9}$ Drawing on the increasing trend towards decentralization in several holding-together federations and quasi-federations, a corpus of studies on territorial politics has identified the centrifugal stress to which state-wide parties are exposed when competing against especially strong, electorally successful, regional parties (Amat and Falcó-Gimeno, 2014; Massetti and Schakel, 2013; Meguid, 2008; Swenden and Maddens, 2009).

${ }^{10}$ After the Sonderbundskrieg, the last civil war among the cantons in 1847, Switzerland became a federal republic in 1848 . Yet, there were non-negligible centrifugal forces still active in the system. Consequently, in the autumn of 1868 , after widespread floods in the Swiss Alps, federal officials launched an aid campaign under the slogan of Unus pro omnibus, omnes pro uno - the Dumasian "One for all, all for one" which is nowadays considered the motto of the country - deliberately using this external threat to evoke a sense of duty and solidarity and national unity in the population.
} 
preferences over authority boundaries in the context of the shock.

Coordination problems are inherent to the day to day elite level functioning of a federation. Scharpf (1997) has extensively studied the dynamics of intergovernmental cooperation and its impact on policy-making. A particularly interesting instance for coordination problems is 'joint decision-making' (Scharpf, 1988; Benz, 2011) in federations. Joint decision-making systematically generates sub-optimal policy solutions, while preventing politicians from tackling coordination problems effectively. As no single actor is able to unilaterally exit the decision-making process, and veto points systematically benefit those actors who support or defend the statu quo, such institutional settings are likely to end up in a 'joint-decision trap' (Benz and Broschek, 2013). Then, in a context like this, the singularity of an external threat rests upon the fact that governments face an unexpected coordination challenge that, rather than being oblivious to citizens, as it regularly happens in federations, suddenly, it becomes salient to them, making general agreement upon the necessity of a solution apparent. Given our genuine interest in the popular side of the reactions to an external threat, the obvious question here is: how will the public move from considering there is a problem in the response to the threat to a consensus on a specific solution? ${ }^{11}$

In the case of a sanitary threat such as the one posed by COVID-19, curbing the spread of the virus in a federation poses a particularly salient collective action problem that can only be overcome with intergovernmental cooperation. A coordinated response to prevent a collective risk is logically more difficult where authority is vertically fragmented, as difficulties in coordination increase with the number of bargaining actors. ${ }^{12}$ The sanitary threat requires an urgent and coordinated response that is hampered by the vertical fragmentation of powers. We here argue that as the threat uncovers problems for coordinated action, central governments in federations become a focal point for citizens (Schelling, 1980). ${ }^{13}$ Consensus with the solution is facilitated by the specific nature of the commonly

\footnotetext{
${ }^{11}$ In Bednar's theoretical model, this would entail moving from stage (III), where there is general agreement on how to solve the problem, but this general agreement is not commonly known, to (IV), where the public agrees with both the problem and the solution and this general concurrence is publicly known $(2008,190)$.

${ }^{12}$ Due to the importance of successful coordination for the functioning of firms, organizations, or industries (Camerer and Knez, 1997; Friedman, 2012; Schelling, 1980), there is a large body of research in economics on coordination games. Since the determinants for coordination failure or success can be more easily controlled for and identified in laboratory studies than in field studies, most of the work on coordination has relied on controlled experiments (Cooper et al., 1990, 1992; Van Huyck, Battalio and Beil, 1990, 1991). While first studies demonstrated that coordination failure among participants was frequent, subsequent research has identified structural factors that facilitate efficient coordination in firms and organizations; among others, financial incentives, communication, and groups' size (Devetag and Ortmann, 2007).

${ }^{13}$ Under normal circumstances, constitutions provide a guide to acceptable behavior; a focal point that coordinates citizens regularly (Hardin, 1989)
} 
acknowledged problem: because the fragmentation of authority causes a suboptimal response to the threat, citizens coordinate their preferences around a prominent and more efficient decision-maker, even if this might require redrawing the statu quo authority boundaries.

In fact, we now know that threats might influence perceptions about who should lead the way out of a crisis. A recent literature trend has connected stealth democracy attitudes (Hibbing and Theiss-Morse, 2002), that is, the idea that people prefer political decisions to be made via expert-based governing arrangements to promote higher levels of efficiency and effectiveness, with the economic reforms and political transformations in the aftermath of the Great Recession (Alexiadou and Gunaydin, 2019; Lavezzolo and Ramiro, 2018; Lavezzolo, Ramiro and Fernández-Vazquez, 2020). These studies suggest that when facing particularly negative and salient economic contexts, in the search of efficient and effective governing solutions, voters' resort to technocratic types of profiles in government. An even more recent group of, mostly experimental, pieces on the political consequences of COVID-19 crisis find that the pandemic has been associated, at least in the short term, with greater support for the incumbent government (Blais et al., 2020; Leininger and Schaub, 2020; Merkley et al., 2020), a strong activation of selective evaluation - with partisanship very relevantly determining support - (Gadarian, Goodman and Pepinsky, 2020; Grossman et al., 2020) and a strong national bias coupled with higher demands for techno-authoritarian decision-making (Amat et al., 2020).

We believe all of the findings above, which present paradigmatic shifts in public attitudes in times of crisis, as well as the still ongoing pandemic, present a unique opportunity to investigate, for the first time in the literature, the effect of external threats on preferences towards vertical distributions of authority in federations. To that end, we develop an online survey experiment to explicitly model this causal relationship by randomly assigning information to participants and measuring their reactions to these stimuli in the context of COVID-19. Below we outline three sets of testable hypotheses. The first one examines the main average effect of interest in the paper. The rest delve into heterogeneous treatment effects, trying to uncover the conditional effect of the main dimensions of party competition for respondents in the sample and thus capture those individual-level perception biases that might be conditioning the described main effect. Particularly, given our focus is on federations and quasifederations, two specific moderators are taken into account: center-periphery territorial preferences and partisanship. The argument underpinning the first one is that the hypothesized consensus around 
the coordinated solution might depend on individuals' preferences towards a more centralized or decentralized form of the state (Alonso, 2012; Pardos-Prado and Sagarzazu, 2019). As for the second one, if partisanship colors attitudes, the idea is to understand to what extent individuals might adjust their view of which level of government should be in charge of managing the crisis depending on the partisan label of multilevel incumbents (Tilley and Hobolt, 2011).

H1. In a context of a particularly salient external threat, giving people in a federation information about multilevel coordination failures will affect how they think vertical authority should be distributed, favoring centralizing reforms.

H2. In a context of a particularly salient external threat, giving people in a federation information about multilevel coordination failures will affect how they think vertical authority should be distributed, dependent on their territorial preferences.

Specifically:

- Exposure to the treatment will have a higher effect on centralization among those with centripetal preferences than among those with centrifugal preferences.

H3. In a context of a particularly salient external threat, giving people in a federation information about multilevel coordination failures will affect how they think vertical authority should be distributed, dependent on their partisanship.

Specifically:

- Exposure to the treatment will have a higher effect on centralization among federal incumbent partisans than among opposition parties' partisans.

\section{Experimental Design}

Federations and quasi-federations with a salient territorial dimension of competition represent particularly interesting cases in which to study popular reactions to an external threat, whether this is military, economic or sanitary. First, as countries with multilevel governments, they face the same 
coordination and scale problems previously identified in the literature. Second, unlike in federations where the territorial dimension is uncontested or subsumed in a broader all-encompassing left-right dimension, these are countries where there are various alternative coalitions of voters across dimensions.

In this sense, the Spanish case represents a particularly good example. As a centrifugal holdingtogether quasi-federation, in the last decade it has suffered an exceptional process of conflict extension (Layman and Carsey, 2002). There has been an extreme process of first ideological, and then territorial preference polarization, particularly after the interconnected consequences of the Great Recession (Vidal, 2018), the secessionist crisis in Catalonia (Simon Cosano, 2020), and the electoral success of VOX (Turnbull-Dugarte, 2019), the first radical right party in the recent democratic history of the country. Consequently, the case gives us the opportunity to identify the popular reactions to a particularly devastating external shock as the one of COVID-19, in a country characterized by frequent internal threats. $^{14}$

We test our hypotheses using a series of online survey experiments with a priming manipulation. Our focus in the Spanish case is short-term (April 2020) and long-term (November 2020). Additionally, with the aim of exploring the external validity of the hypothesized effect, we develop a cross-sectional study in 12 federations, quasi-federations and decentralized unitary systems worldwide (June 2020). Working with such a heterogeneous group of countries may introduce large doses of noise in our analyses. Yet, we believe the coordination problems that motivate this study might actually be common to countries with decentralized decision-making, being federations and their particular multilevel power distribution arrangements, the epitome of the contexts we are interested in further exploring here. Accordingly, regardless of the probable differences in the baseline or magnitude of the effect across countries, we expect to see our first hypothesis confirmed virtually in all of the selected cases.

Our treatment consists of a statement in which we expose a randomly selected group of participants to information about World Health Organization's (WHO) recommendations with respect to governmental coordination and the difficulties of multilevel cooperation in each of the 13 selected

\footnotetext{
${ }^{14}$ For instance, in the autumn of 2019, as a reaction to the Spanish Supreme Court's ruling in the case against the secessionist leaders that promoted a unilateral referendum and independence declaration in 2017, Catalonia experienced days of protests and riots: https://www.nytimes.com/2019/10/18/world/europe/catalonia-separatist-belgium.html
} 
countries. ${ }^{15}$

The exact wordings are as below:

Treatment group. The World Health Organization has warned countries about the importance of collaboration and coordination between governments in the fight against the COVID-19. However, experts have pointed out that the management of the crisis is being particularly difficult in Spain due to the collaboration and cooperation problems between the central government and the regions. Which should be the actual power distribution between the central government and the regions?

[0-10 scale provided to respondents where 0 means "Grant more power to the regions", 5 "Statu quo" and 10 "Grant more power to the central government"]

Control group. Which should be the actual power distribution between the central government and the regions? [0-10 scale provided to respondents where 0 means "Grant more power to the regions", 5 "Statu quo" and 10 "Grant more power to the central government"]

In order to study the effect of exposure to multilevel coordination failures on public preferences towards vertical distribution of power, we estimate a set of OLS models, with standard errors clustered at the regional level, that include individual controls as well as a set of regional fixed effects. The inclusion of individual controls and regional fixed effects is important for several reasons. First, because individuals' reaction to the virus might be driven by individual characteristics. Specifically, we control for age, gender, education, being unemployed, being affected by a lay-off as a consequence of the pandemic, as well as individual exposure to the COVID-19 shock (it takes the value 1 if someone in the personal network of the respondent dies after infection). ${ }^{16}$ Second, because the intensity of the virus outbreak in Spain had significant variation across the regions. Third, there might be a compound treatment effect between the outbreak and the slightly varying political and institutional responses to fight it across regions.

\footnotetext{
${ }^{15}$ The experiment was pre-registered at Evidence in Governance and Politics, EGAP.

${ }^{16}$ Table A1 in the Appendix reports covariate balance tests across our treatment and control groups in our first Spanish sample. Because of randomization, there are almost no statistical differences across groups. This also shows up across models in this manuscript and in the Appendix: the estimates are very stable after including a number of additional covariates.
} 


\section{Study 1. Short-Term Effect in Spain}

For the first study, we use a representative sample of the Spanish voting-age population $(\mathrm{N}=2,600){ }^{17}$ The survey experiment was developed in mid-April, when Spain had been locked down for a month, and was ranking second in the world regarding the total number of contagions and first regarding number of per capita deaths. In order to make the lock down effective, Spain adopted the state of alarm, a constitutional measure that allowed central government to suspend regional powers temporarily.

\section{i. Average Treatment Effects}

In Figure 1, we show the average treatment effect of the priming manipulation experiment we present above for the whole sample, with control variables. The mean of the reported preferred vertical distribution of power is around 5.5 in a scale from 0 to 10 for the whole sample, which suggests that, on average, our respondents located themselves around the territorial statu quo in Spain. Moreover, the ATE is around 0.7, which also confirms that, in the particular context of the pandemic, those who were exposed to multilevel coordination failures significantly chose to grant more power to the central government.

Figure 1: Average Treatment Effect on Preferred Territorial Distribution

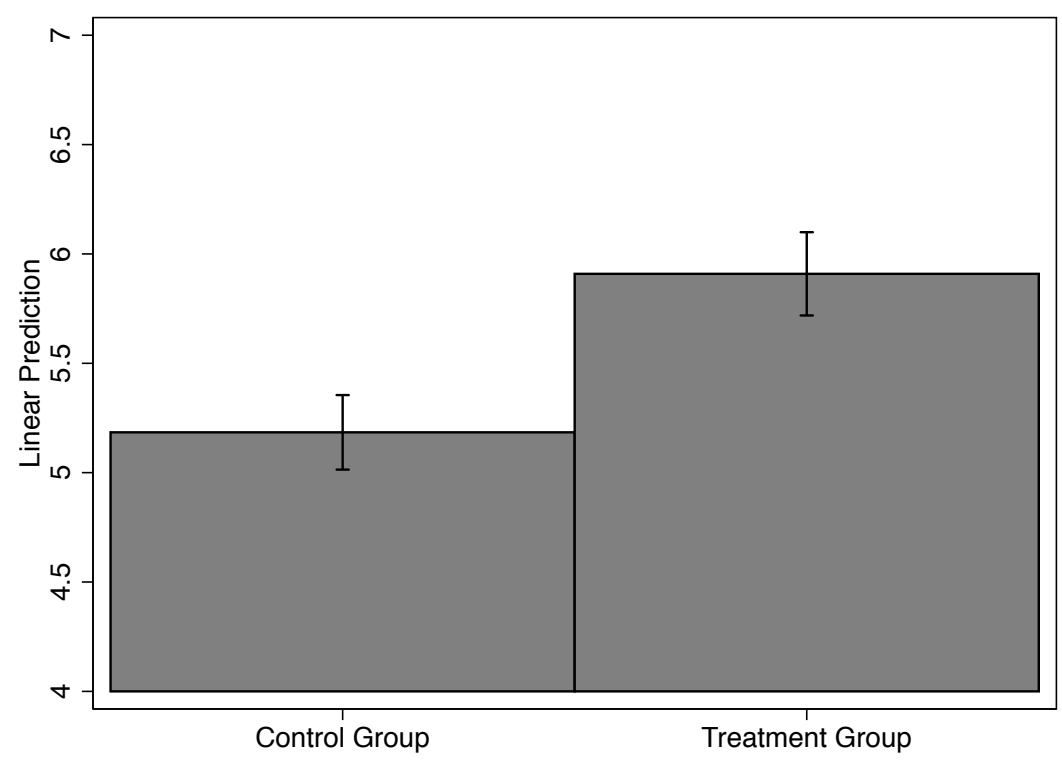

\footnotetext{
${ }^{17}$ The online survey was implemented by Netquest between April $15^{\text {th }}$ and $18^{\text {th }}$. Respondents were recruited using age, gender and region quotas in order to mirror the actual distribution of these variables
} 
Likewise, in Table 1 we consider the validity of the effect by linking the treatment to specific policy domains. Particularly, right after the general question on preferred vertical distribution of power, we asked respondents about their preferred multilevel distribution of power on Health Care, Taxes and Security. We believe that these results should be connected to the nature of the external threat. The treatment seems to have a particularly significant effect on policy domains that are managerial and sanitary in essence. The treatment shows a marginally significant effect on the centralization of security competences, but when estimated with a more conservative specification in the Appendix loses its significance. This policy domain seems to be perceived by respondents as less necessary in the fight against the COVID-19. This result becomes particularly relevant in light of the previous theoretical discussion on the necessary conditions for a centralized federal bargain to happen when facing an external threat. In the context of the pandemic, respondents seem to favor some particular measures over others.

Table 1: The Effect Across Policy Domains

\begin{tabular}{lccc}
\hline \hline & Health Care & Taxes & Security \\
\hline \multirow{2}{*}{ Treatment } & $0.358^{* *}$ & $0.443^{* * *}$ & $0.256^{*}$ \\
& $(0.146)$ & $(0.139)$ & $(0.138)$ \\
\hline Control Variables & $\checkmark$ & $\checkmark$ & $\checkmark$ \\
Region Fixed-Effects & $\checkmark$ & $\checkmark$ & $\checkmark$ \\
Mean Dep. Var. & 5.490 & 5.186 & 4.874 \\
\hline$N$ & 2,176 & 2,145 & 2,181 \\
\hline \hline \multicolumn{4}{c}{$p<0.01,{ }^{* *} p<0.05,{ }^{*} p<0.1$} \\
\end{tabular}

\section{ii. The Moderating Effect of Territorial Preferences and Identity}

Our second hypothesis explores the extent to which the existence of a second dimension of competition in Spain conditions the treatment. In Figure 2, we use a five point ordinal variable that categorizes respondents' preferred territorial distribution of power, using the actual statu quo as a baseline. Respondents are asked to choose a position from a range of options along a single dimension whose extreme points are "I prefer a state where regions have the right to secession" and "I prefer a unitary state without regions".

Contrary to our expectation, the effect of the treatment is not only restricted to centripetal territorial preferences but is extensible to the whole range of positions. That is, randomly treated respondents 
favored centralizing positions regardless of their previous territorial preferences. In fact, paradoxically, the magnitude of the effect is relatively larger among respondents with centrifugal positions than among those with centripetal ones (from a 1.3 point jump among those that favor secession to barely 0.3 among those that want a unitary country). Two relevant observations should be made here. First, we are not dealing with any ceiling effect; the mean of this independent variable is $3.23(1-5)$ and its distribution, if something, is skewed to the left. Second, given the steep increase in centralizing preferences as territorial preferences become more centripetal, we might be just facing the fact that pro-centralization positions are reaching a saturation point in the scale.

Figure 2: The Effect Across Respondents' Previous Territorial Preferences

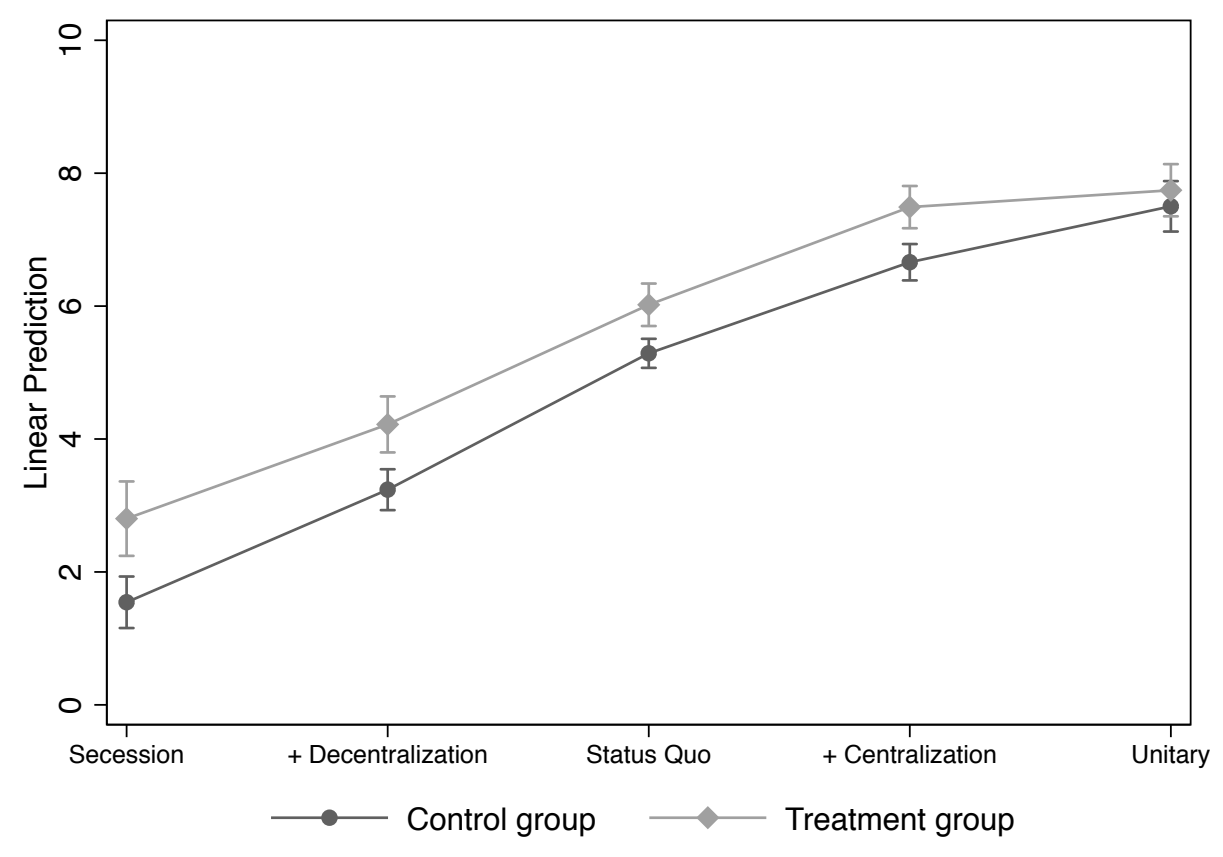

In Figure 3 we try to delve deeper into the identity side of this dimension by using the so-called Linz-Moreno question. This question, first developed by Linz in the context of Spain (1981, 519-48), asks respondents to choose a position from a range of options along a single dimension whose extreme points are "I feel only [regional]" and "I feel only [national]". ${ }^{18}$ The results in Figure 3 present interesting caveats that deserve further comment. Mainly, we see a similar effect to the one in the previous figure. That is, the treatment increases pro-centralization preferences across alternative identities,

\footnotetext{
${ }^{18}$ Despite its widespread use, the measure has been the focus of some validity oriented criticism lately (Guinjoan and Rodon, 2015; Sinnot, 2006). While we recognize the pertinence of most of these remarks, given its tradition in Spain and the absence of a widespread used alternative, we believe it still presents a necessary complement to the previous purely distributional moderator.
} 
especially, again, among those with moderate identities. Interestingly, for those with extreme identities the treatment loses its significance, suggesting that a different, and non-territorial, logic might be in place. For instance, the fact that those individuals with single territorial identities have historically been mainly identified with political parties other than those holding the incumbency at the federal level (particularly, regionalist, secessionist, and right-wing nationalist parties). Next section explores some of these partisan dynamics.

Figure 3: The Effect Across Respondents' Territorial Identities

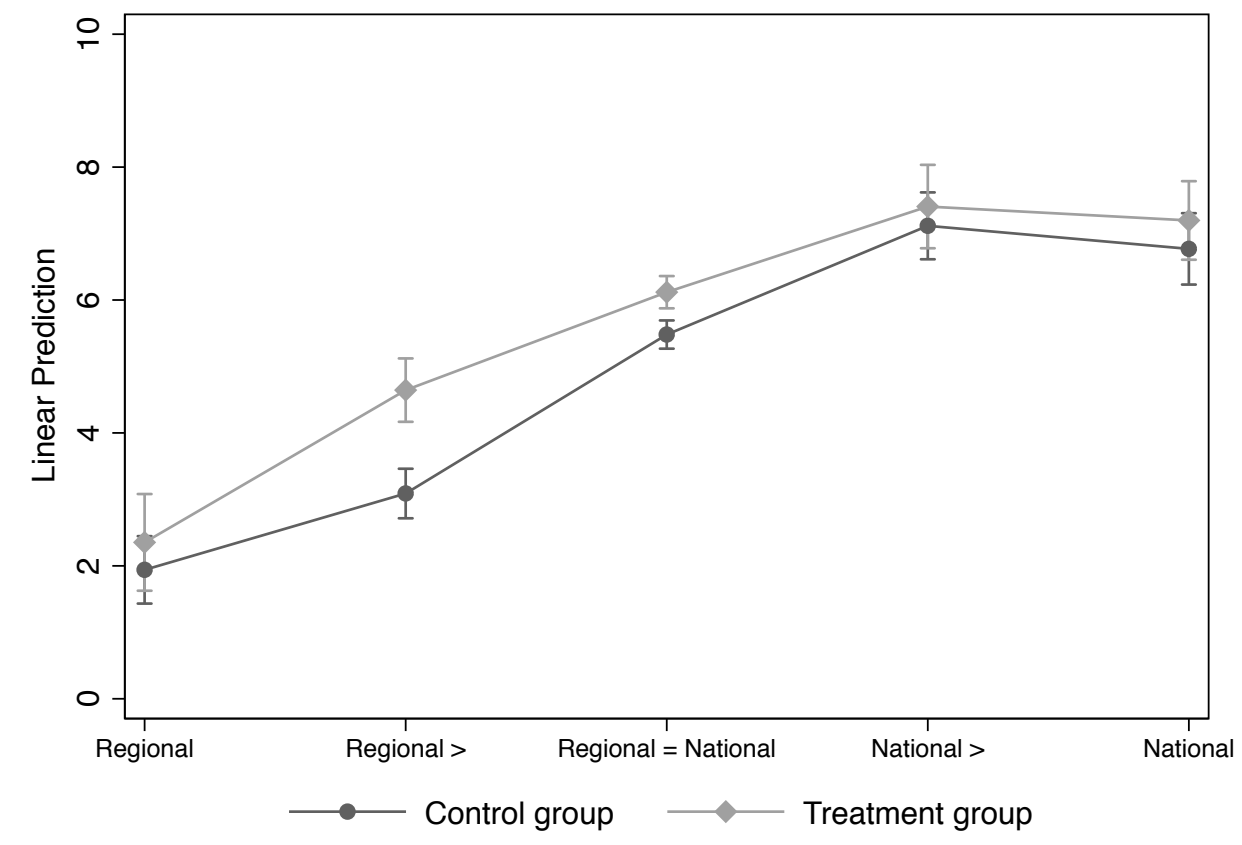

\section{iii. The Moderating Effect of Partisanship}

Our third hypothesis investigates respondents' potentially selective process of distributing authority to different levels of government. Particularly, we are interested in testing for the role of partisanship when shaping the treatment. To that end, we asked respondents to report the party to which they would be willing to vote at that specific moment. In Figures 4 to 6, we present the results for government left-wing coalition partners' voters (PSOE and Podemos), statewide right-wing opposition parties' voters (PP, VOX and Ciudadanos), and regionalist parties' voters. Specifically, we compare the behavior of voters in each of these groups to the rest of the respondents' in the sample.

The results strongly support our expectation. Treated PSOE and Podemos voters significantly differ 
in their pro-centralizing preferences from non-treated ones. These findings provide an extremely neat graphical evidence of the way in which partisanship and, in this case, willingness to vote to federal incumbent parties, influences the way in which people distribute vertical authority when exposed to a coordination failure. Centralization becomes a suitable measure for individuals when those elites that are closer to their preferences are in charge of delivering a coordinated solution. ${ }^{19}$

Figure 4: The Effect among Federal Coalition Parties' Voters

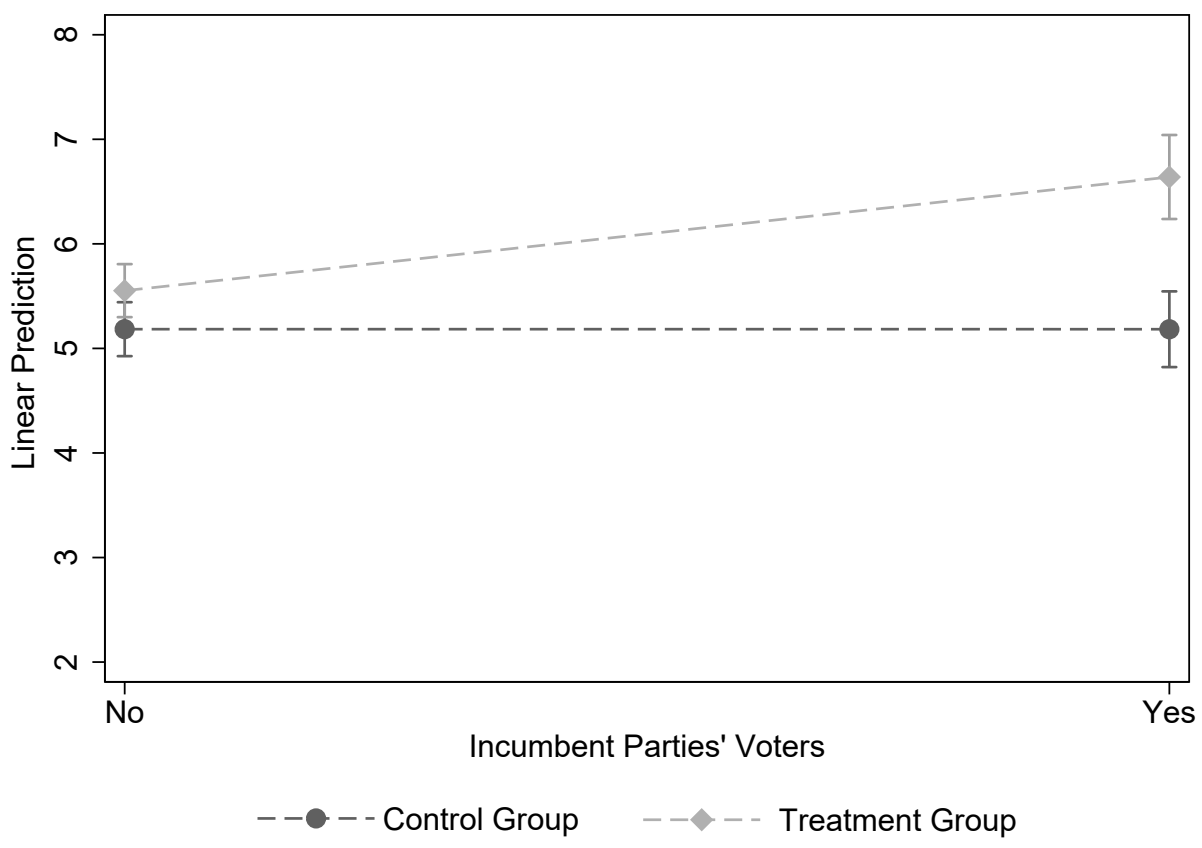

Figure 5 presents an additional proof of this behavior. On average, PP, Vox and Ciudadanos voters in the control group show a more centralizing position than the rest of the respondents in the control group, showing a position that very much mirrors that among the rest of the treated in the sample. Interestingly, the graph shows that among the treated statewide opposition parties' voters, learning about multilevel coordination failures doesn't show any significant difference in their preferences. In fact, this generally, on average, more pro-centralization group of voters is the one with the smallest treatment effect in our sample.

Yet, as a highly polarized quasi-federation with prominent internal threats, the presence of regional and secessionist political parties in the Spanish Lower Chamber was exceptionally high at the time of

\footnotetext{
${ }^{19}$ The latter issue becomes particularly relevant in the case of Podemos, a party that, on average, has voters that are more pro-decentralization than the rest of the respondents. Even if this is the case, in the Appendix we show that the effect of the treatment on Podemos voters follows the same positive and significant path that the one found among PSOE voters: indeed, there is a 1.8 point difference between treated and non-treated Podemos voters.
} 
Figure 5: The Effect among Federal Statewide Opposition Parties' Voters

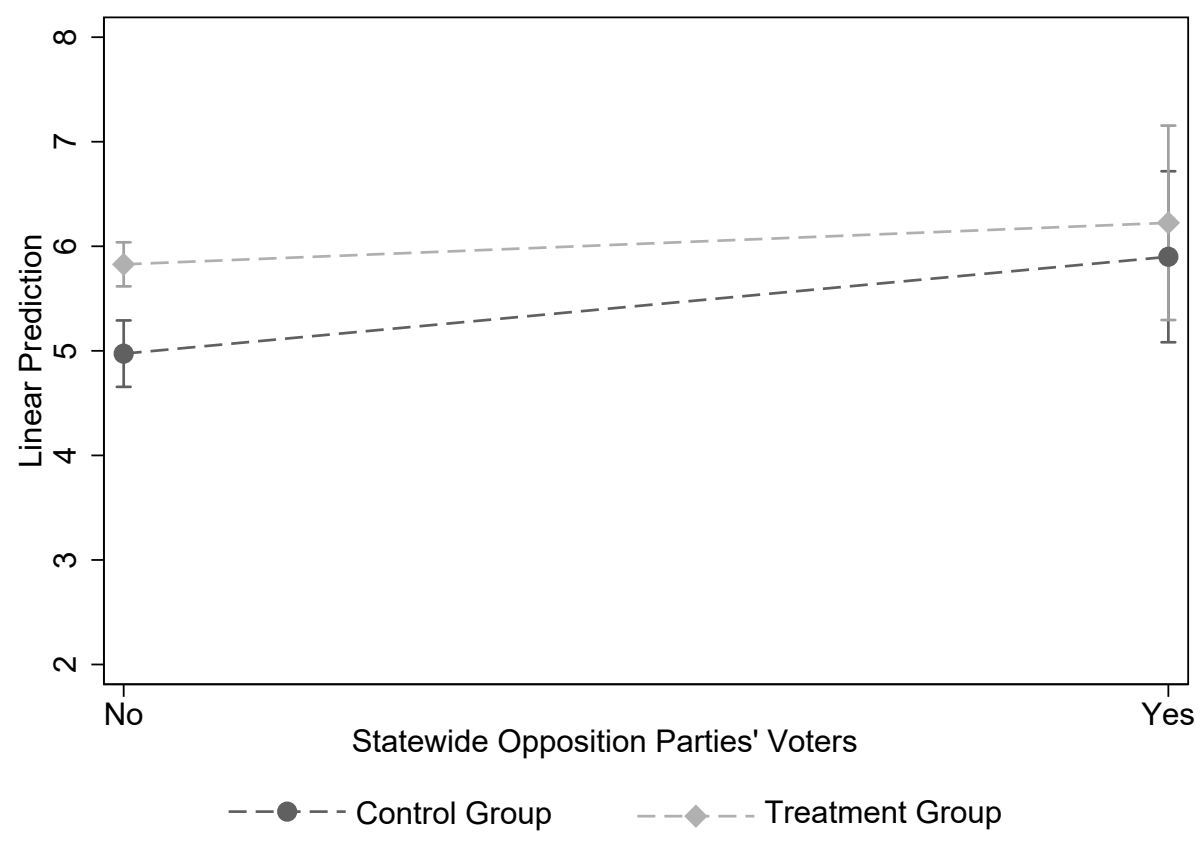

the pandemic. Five out of the ten parliamentary groups were of this kind, that is sixteen out of the twenty-three political parties with representation. In order to capture the conditional effect of regional and secessionist partisanship on the treatment, we group all of these voters together in Figure 6. The effects in the graph necessarily complement the previous two. As observable, this group of voters shows a much more pro-decentralization position than the rest (the average difference between both control groups is of 3 points in our dependent variable's 0 to 10 scale). Moreover, even if it fails to reach significance, the treatment effect among regionalist voters is of around 1 point.

\section{iv. The Territorial Patterns of the Heterogeneous Effects}

Do these moderating effects follow a territorial pattern? If, as demonstrated, the individual level vertical distribution of authority follows a highly selective pattern, we should expect this effect to vary depending on the particular partisan label of regional incumbents too. In Spain, 14 out of the 17 total regions had a premier that belonged to PSOE (9) or to PP (5), alone or in coalition, at the time of the survey. The other 3 (Basque Country, Cantabria, and Catalonia) had premiers belonging to regional parties, though the PSOE was part of the incumbent coalition in the first two. In order to capture some of these dynamics, in Figure 7 we have separated the previous heterogeneous treatment effects 
Figure 6: The Effect among Regiona Parties' Voters

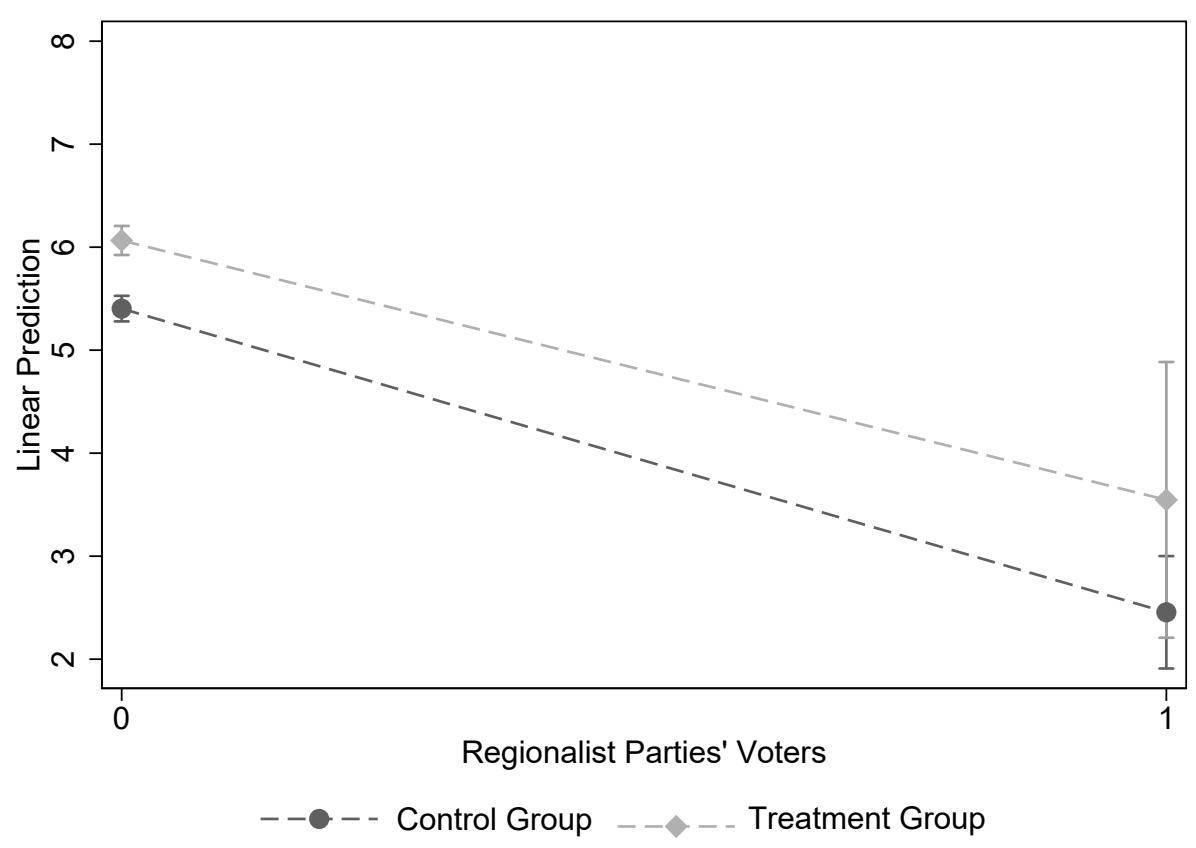

depending on the color of the regional government. In the first column, there are two scenarios of indifference; that is, being a PSOE voter in a region governed by PSOE and being a PP voter in a region governed by PSOE, both represent two scenarios in which, for different reasons, we shouldn't expect to see significant differences between treated and controlled groups. PSOE voters in these regions live in jurisdictions not only aligned with their preferences, but also with those of the central government, and thus, as we find, there shouldn't be particular reasons to select one level of government upon the other one. As for the PP voters in regions governed by the PSOE, given their distance to both federal and regional incumbents, it wouldn't be unfair to say that these are voters trapped in unfavorable contexts, and thus, as we find, they do not have a particular reason to select one level of government upon the other one.

The incentives change in the second column, where voters of each party have the possibility of assigning more authority to the one level governed by their party. This is the case of those PSOE voters living in regions governed by the PP. As observable, among those who learned about coordination failures, the centripetal effect is extraordinary, with levels of authority distribution of around 8 points in the scale of reference. As for those PP voters living in regions governed by the PP, the effect among the treated is negative and marginally non-significant. Taken together, both graphs neatly 
exemplify the extent to which the Spanish multilevel political scenario interacts with our treatment effect, showing how even in times of the pandemic, there are important territorial dynamics that shape the way in which perceptions about coordination failures interact with individual level partisan biases.

Figure 7: Aligned and Non-Aligned Regions
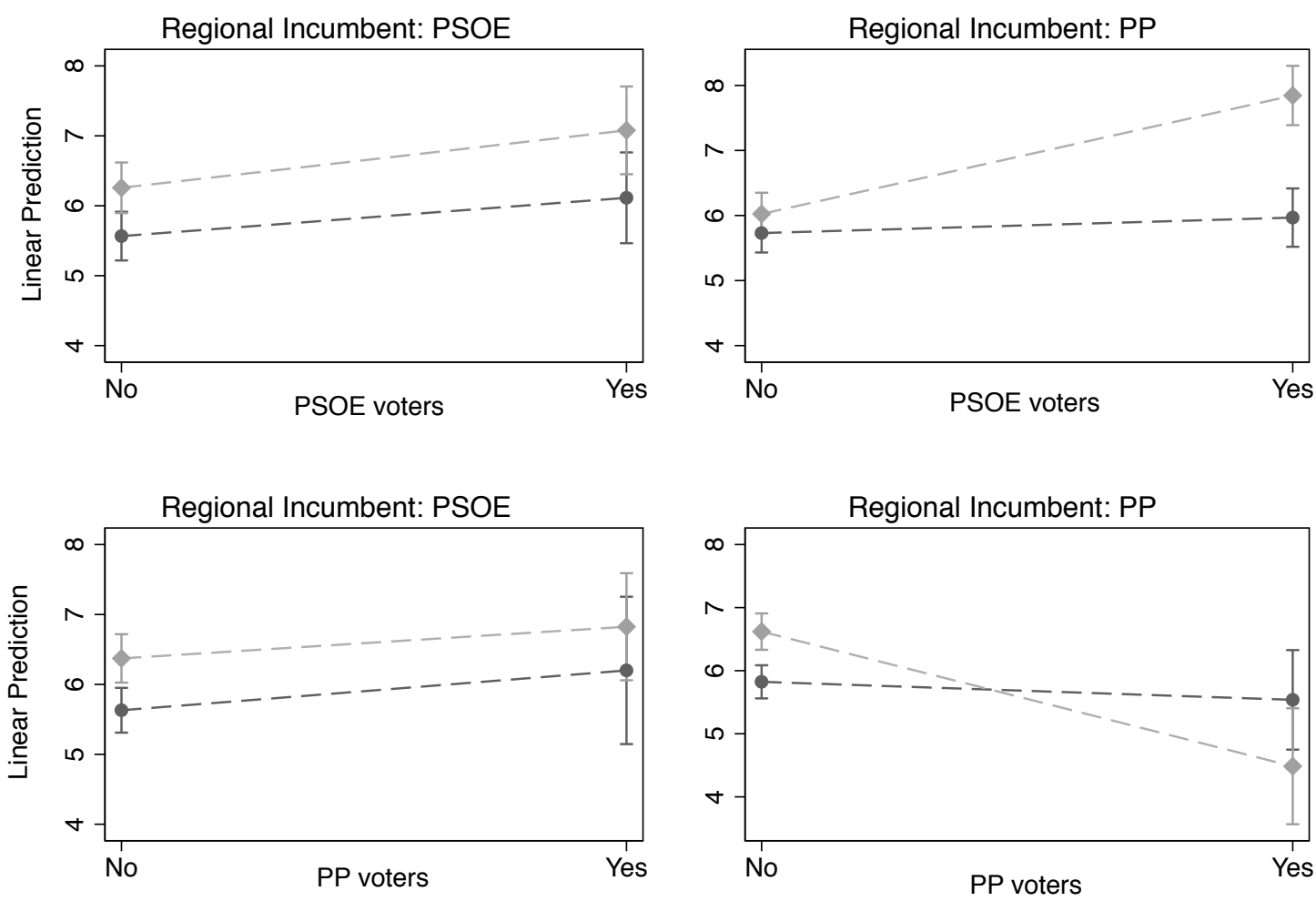

\section{Study 2. Long-Term Effect In Spain}

For the second study, we use a smaller but still representative sample of the Spanish voting-age population $(\mathrm{N}=1,200) \cdot{ }^{20}$ The survey experiment was developed between October and November, in the midst of the second wave of the pandemic. However, unlike in April, Autonomous Communities were in charge again of the management of the crisis, this time coordinated via a federal multilateral Council composed by the central government's Minister of Health and his regional counterparts. In the beginning of June, once the first wave of the pandemic started to be under control, the central gov-

\footnotetext{
${ }^{20}$ The online survey was implemented by Netquest between October $29^{\text {th }}$ and November $4^{\text {th }}$. As in the previous survey, respondents were recruited using age, gender and region quotas in order to mirror the actual distribution of these variables.
} 
ernment devolved the health service management back to the regions, which hold the decentralized power in this regard, and remained like that ever since then. To prove that the changes between both moments were popularly perceived at the time of the survey, Table 2 presents the average responses to the question "Who do you think is the main responsible of how the pandemic has been managed in your region"?

Table 2: Main Responsible Level of Government

\begin{tabular}{lcc}
\hline \hline & Spring (\%) & Fall (\%) \\
\hline European Union & 5.90 & 2.58 \\
Central government & 57.22 & 47.88 \\
Regional government & 27.19 & 39.63 \\
Local government & 0.46 & 0.83 \\
Don't know & 2.26 & 2.41 \\
Don't answer & 6.97 & 6.66 \\
\hline Total & 100 & 100 \\
\hline \hline
\end{tabular}

In the second moment, there is a clear decrease among those respondents choosing the central government, and a clear increase among those choosing their regional governments; the rest of the categories remain, more or less, the same. This is relevant descriptive evidence motivating the purpose of investigating the effect in the long-term: that is, the possibility of replicating our experiment and comparing our results in moments in which the main responsible level of government was different but the severity of the pandemic was otherwise similar and thus comparable. Table 3 compares the ATE in both moments and confirms, once again, its positive direction and significance. ${ }^{21}$ Interestingly, the baseline in the control group is higher during the fall than during the spring, though the magnitude of the effect is practically the same. As it appears, in the absence of an effective solution, six months later of the appearance of the COVID-19, the persistence of the threat continued to increase procentralization tendencies in Spain, even under an alternative territorial model of crisis management and with a public that had already experienced a pro-centralization drift.

\section{Study 3. The Effect in a Comparative Sample}

As important as understanding the duration of the identified effect is to be able to relate it to comparable trends in institutionally similar contexts. Decentralized decision-making is an extended territorial

\footnotetext{
${ }^{21}$ The model controls for respondents' sex, age, employment situation, being affected by a lay-off, having a fatal covid experience and regional fixed-effects. Standard errors are also clustered by region.
} 
Table 3: Comparing the ATE in both moments

\begin{tabular}{cccc}
\hline Time & Control Group & Treatment Group & Difference \\
\hline Spring $\mathbf{2 0 2 0}(\mathbf{N}=\mathbf{2 , 1 9 9 )}$ & 5.18 & 5.90 & $0.72^{* * *}$ \\
Fall $\mathbf{2 0 2 0}(\mathbf{N}=\mathbf{1 , 0 3 3 )}$ & 5.47 & 6.15 & $0.68^{* *}$ \\
\hline \hline
\end{tabular}

model of government organization across all world latitudes that, theoretically, in the presence of an external threat, should face the same challenges that have been identified in this paper. To properly test for the comparative dimension of the identified effect, we repeated our experiment our priming experiment in June 2020, in a sample of federations, quasi-federations and decentralized unitary countries worldwide: ${ }^{22}$ Australia, Austria, Brazil, Canada, France, Germany, Italy, New Zealand, Poland, Sweden, United Kingdom and United States of America.

Having such an institutionally diverse set of countries presents a unique comparative opportunity for our study. The sample represents some of the most affected democracies by the COVID-19 pandemic at the time - a group of countries where the external threat was clear and widespread. Moreover, the debate about the centralized versus decentralized management of the crisis has been a salient one, even among decentralized unitary countries in our sample. For instance, on September 24, French Prime Minister Jean Castex called for a regionalized approach, defending that "most of the measures should not be decided from Paris".$^{23}$ Furthermore, countries like Sweden have a fully decentralized healthcare system, with responsibility lying within regional councils and, in some cases, within municipalities and local governments. We pool all of these countries together, and, besides the individual level controls used in previous models, we also control for respondents' ideology, central government incumbent party voters, and the Regional Authority Index scores (Hooghe et al., 2016). ${ }^{24}$ Given the existing institutional heterogeneity among the countries in our sample, introducing the RAI gives us the possibility of controlling for the part of the variation in individual level expectations that depends on the actual decision-making authority of each of these territorial levels.

As shown in Figure 8, the effect is positive in every single country, reaching significance in Australia, Austria, Brazil, France, Germany, New Zealand, and Poland $(\mathrm{N}=9,324)$. Results confirm that

\footnotetext{
${ }^{22}$ We use Bednar (2008) to classify them according to their territorial structures.

${ }^{23}$ France 24, 2020/09/13: "Covid-19: Fearing a second wave, the French government is relying on a local strategy"

${ }^{24}$ In the Appendix, we also introduce regional level deviations from country average per capita deaths at the time of the survey to control for regional level incidence of the virus. Results hold although they lose some magnitude and significance.
} 
learning about coordination problems activates the same underlying solution mechanism among the different audiences of this varied group of countries. Interestingly though, while all of the average power distributions by country are located around 5, that is, the status quo, five out of six of the federations in the sample show pro-centralization average positions among the control and the treatment groups. On the contrary, it is among unitary and quasi-federal countries, such as, France, Poland or the United Kingdom, were we find the most pro-decentralization average positions. These countries seem to depart from slightly different baselines, which might be related to their territorial structures and the existing, country specific, average political expectations in this regard.

Figure 8: Comparative Analysis of the Effect

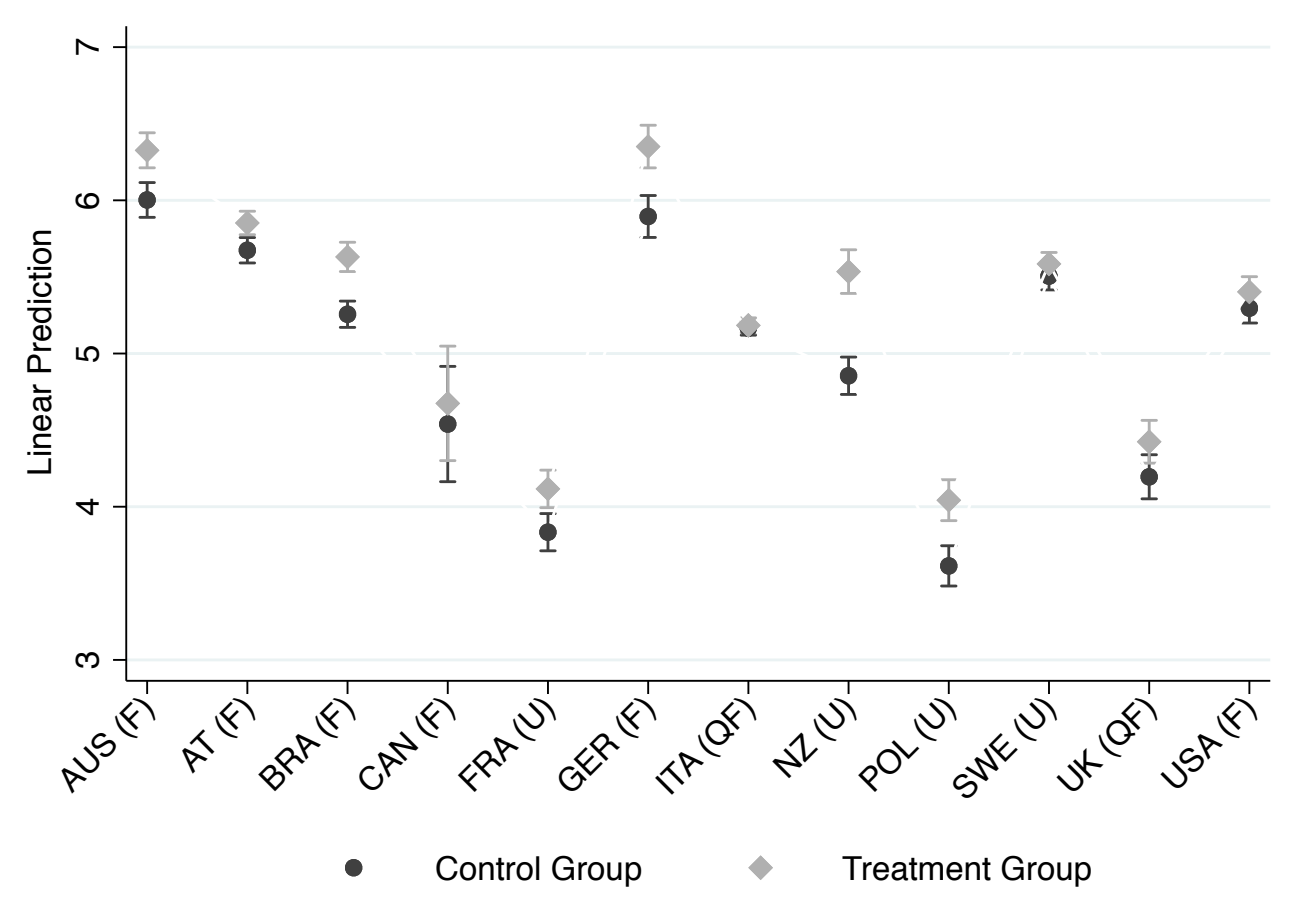

VIII. CONCLUSION

The outbreak of the COVID-19 pandemic has presented a unique opportunity to understand whether citizens' preferences over multilevel authority boundaries change as a result of an external threat like this. Our main argument is that external threats turn intergovernmental coordination into a salient issue for citizens because they compel governments to provide a rapid coordinated response. As citizens acknowledge that coordination represents a problem to tackle the threat, the central government 
emerges as a focal point in the solution. Citizens coordinate their preferences around a more efficient decision-making process that consists in the centralization of authority and thus the reduction of the number of decision-makers.

Using several survey experiment analyses based on on-line samples in Spain, and 12 other countries, we have shown that citizens that are primed on problems of intergovernmental cooperation in fighting the COVID-19 are more likely to support centralization. Results also show that this centralizing drift is moderated by territorial preferences and ideology, that it survives in time as long as the threat is salient, and that the effect on popular preferences has a comparative nature and thus travels across decentralized but institutionally heterogeneous countries.

These empirical findings have some implications regarding one of the most important theoretical questions in the area of federal studies: the stability of the federation and its drivers. Although shifts in citizens' preferences over authority boundaries may fade away when the exposure to a shock ends, popular reactions to external threats may have an impact over the federal bargain that outlasts them. Once popular preferences for a redrawing of authority boundaries are publicly acknowledged, changes in the distribution of authority may follow in the form of beneficial adjustments but also in the form of opportunistic transgressions. As Bednar $(2008$, 8) states "distributing authority requires rules, and rules may be broken". 


\section{REFERENCES}

Alesina, Alberto and Enrico Spolaore. 1997. “On the number and size of nations.” The Quarterly Journal of Economics 112(4):1027-1056.

Alesina, Alberto, Enrico Spolaore and Romain Wacziarg. 2000. "Economic integration and political disintegration." American Economic Review 90(5):1276-1296.

Alexiadou, Despina and Hakan Gunaydin. 2019. “Commitment or expertise? Technocratic appointments as political responses to economic crises." European Journal of Political Research 58(3):845-865.

Alonso, Sonia. 2012. Challenging the State: Devolution and the Battle for Partisan Credibility: A Comparison of Belgium, Italy, Spain, and the United Kingdom. Oxford University Press.

Amat, Francesc and Albert Falcó-Gimeno. 2014. "The legislative dynamics of political decentralization in parliamentary democracies." Comparative Political Studies 47(6):820-850.

Amat, Francesc, Andreu Arenas, Albert Falcó-Gimeno and Jordi Muñoz. 2020. “Pandemics meet democracy. Experimental evidence from the COVID-19 crisis in Spain.".

Amoretti, Ugo M. and Nancy G. Bermeo. 2004. Federalism and territorial cleavages. JHU Press.

Bakke, Kristin M and Erik Wibbels. 2006. "Diversity, disparity, and civil conflict in federal states." World Politics 59(1):1-50.

Bednar, Jenna. 2008. The robust federation: Principles of design. Cambridge University Press.

Benz, Arthur. 2011. Escaping joint-decision traps: National and supranational experiences compared. In The EU's Decision Traps: Comparing Policies. Oxford University Press, UK pp. 199-216.

Benz, Arthur and Jörg Broschek. 2013. Federal Dynamics: Introduction. In Federal Dynamics: Continuity, Change, and the Varieties of Federalism. Oxford University Press, UK pp. 1-26.

Beramendi, Pablo. 2012. The political geography of inequality: regions and redistribution. Cambridge University Press.

Beramendi, Pablo and Daniel Stegmueller. 2020. "The Political Geography Of The Eurocrisis." World Politics . 
Beramendi, Pablo and Melissa Rogers. 2019. "Fiscal decentralization and the distributive incidence of the Great Recession." Regional Studies pp. 1-16.

Birch, Anthony H. 1966. "Approaches to the Study of Federalism." Political Studies 14(1):15-33.

Blais, André, Damien Bol, Marco Giani and Peter John Loewen. 2020. “The effect of COVID-19 lockdowns on political support: Some good news for democracy?" European Journal of Political Research (https://doi.org/10.1111/1475-6765.12401).

Brennan, Geoffrey and James M. Buchanan. 1980. The power to tax: Analytic foundations of a fiscal constitution. Cambridge University Press.

Camerer, Colin and Marc Knez. 1997. Organizational decision making. In Coordination in organizations: A game-theoretic perspective. Cambridge University Press Cambridge, UK pp. 158-188.

Cooper, Russell, Douglas V De Jong, Robert Forsythe and Thomas W Ross. 1992. "Forward induction in coordination games." Economics Letters 40(2):167-172.

Cooper, Russell W, Douglas V DeJong, Robert Forsythe and Thomas W Ross. 1990. “Selection criteria in coordination games: Some experimental results." The American Economic Review 80(1):218-233.

Dandoy, Régis and Arjan Schakel. 2013. Regional and national elections in Western Europe: territoriality of the vote in thirteen countries. Springer.

de Figueiredo Jr, Rui JP and Barry R Weingast. 2005. "Self-enforcing federalism." Journal of Law, Economics, and Organization 21(1):103-135.

Devetag, Giovanna and Andreas Ortmann. 2007. “When and why? A critical survey on coordination failure in the laboratory." Experimental economics 10(3):331-344.

Dikshit, Ramesh Dutta. 1971. “Military Interpretation of Federal Constitutions: A Critique.” The Journal of Politics 33(1):180-189.

Dixit, Avinash and John Londregan. 1996. "The determinants of success of special interests in redistributive politics." the Journal of Politics 58(4):1132-1155.

Elias, Anwen, Edina Szöcsik and Christina Isabel Zuber. 2015. "Position, selective emphasis and framing: How parties deal with a second dimension in competition." Party Politics 21(6):839-850. 
Filippov, Mikhail, Peter C Ordeshook and Olga Shvetsova. 2004. Designing federalism: A theory of selfsustainable federal institutions. Cambridge University Press.

Friedman, James W. 2012. Problems of coordination in economic activity. Springer Science \& Business Media.

Gadarian, Shana Kushner, Sara Wallace Goodman and Thomas B Pepinsky. 2020. "Partisanship, health behavior, and policy attitudes in the early stages of the COVID-19 pandemic." SSRN (preprint), Posted March 27.

Garrett, Geoffrey and Jonathan Rodden. 2006. Globalization and fiscal decentralization. In Globalization and Self-Determination: Is the Nation-State Under Siege? Routledge pp. 87-109.

Gibson, Edward L, Ernesto Calvo and Tulia Falleti. 2004. Reallocative federalism: territorial overrepresentation and public spending in the Western Hemisphere. In Federalism and democracy in Latin America. Johns Hopkins University Press pp. 173-196.

Grossman, Guy, Soojong Kim, Jonah Rexer and Harsha Thirumurthy. 2020. "Political partisanship influences behavioral responses to governors' recommendations for COVID-19 prevention in the United States." Available at SSRN 3578695 .

Guinjoan, Marc and Toni Rodon. 2015. "A scrutiny of the Linz-Moreno question." Publius: The Journal of Federalism 46(1):207-219.

Hardin, Russell. 1989. Why a Constitution? In The Federalist Papers and the New Institutionalism. New York: Agathon.

Hibbing, John R and Elizabeth Theiss-Morse. 2002. Stealth democracy: Americans' beliefs about how government should work. Cambridge University Press.

Hooghe, Liesbet, Gary Marks, Arjan H Schakel, Sandra Chapman Osterkatz, Sara Niedzwiecki and Sarah Shair-Rosenfield. 2016. Measuring regional authority: A postfunctionalist theory of governance. Vol. 1 Oxford University Press.

Inman, Robert P and Daniel L Rubinfeld. 1997. "Rethinking federalism." Journal of economic perspectives 11(4):43-64. 
Jurado, Ignacio and Sandra León. 2020. “Economic globalization and decentralization: A centrifugal or centripetal relationship?" Governance .

Kincaid, John and Richard L Cole. 2011. "Citizen attitudes toward issues of federalism in Canada, Mexico, and the United States." Publius: The Journal of Federalism 41(1):53-75.

Kincaid, John and Richard L Cole. 2015. "Citizen evaluations of federalism and the importance of trust in the federation government for opinions on regional equity and subordination in four countries." Publius: The Journal of Federalism 46(1):51-76.

Kymlicka, Will. 2005. Is federalism a viable alternative to secession? In Theories of secession. Routledge pp. 121-160.

Lavezzolo, Sebastián and Luis Ramiro. 2018. "Stealth democracy and the support for new and challenger parties." European Political Science Review 10(2):267-289.

Lavezzolo, Sebastian, Luis Ramiro and Pablo Fernández-Vazquez. 2020. “The Will for Reason: Voter Demand for Experts in Office." Manuscript 11.

Layman, Geoffrey C and Thomas M Carsey. 2002. "Party polarization and" conflict extension" in the American electorate." American Journal of Political Science pp. 786-802.

Leininger, Arndt and Max Schaub. 2020. "Voting at the dawn of a global pandemic.".

Maddox, William P. 1941. "The political basis of federation." American Political Science Review 35(6):1120-1127.

Massetti, Emanuele and Arjan H Schakel. 2013. “Ideology matters: Why decentralisation has a differentiated effect on regionalist parties' fortunes in W estern democracies." European Journal of Political Research 52(6):797-821.

Meguid, Bonnie. 2008. Party competition between unequals.

Merkley, Eric, Aengus Bridgman, Peter John Loewen, Taylor Owen, Derek Ruths and Oleg Zhilin. 2020. "A Rare Moment of Cross-Partisan Consensus: Elite and Public Response to the COVID-19 Pandemic in Canada." Canadian Journal of Political Science/Revue canadienne de science politique pp. 112. 
Muñoz, Jordi and Raul Tormos. 2020. "Economic expectations and support for secession in Catalonia: between causality and rationalization." European Political Science Review 7(2):315-341.

Oates, Wallace E. 1972. Fiscal federalism. Edward Elgar Publishing.

Oates, Wallace E. 1999. “An essay on fiscal federalism." Journal of Economic Literature 37(3):1120-1149.

Oates, Wallace E. 2005. "Toward a second-generation theory of fiscal federalism." International tax and public finance 12(4):349-373.

Pardos-Prado, Sergi and Inaki Sagarzazu. 2019. “Economic performance and center-periphery conflicts in party competition." Party Politics 25(1):50-62.

Qian, Yingyi and Barry R Weingast. 1997. "Federalism as a commitment to reserving market incentives." Journal of Economic perspectives 11(4):83-92.

Riker, William H. 1964. Federalism: Origin, operation, significance. Little, Brown.

Rodden, Jonathan. 2006. Hamilton's paradox: the promise and peril of fiscal federalism. Cambridge University Press.

Rodden, Jonathan and Erik Wibbels. 2002. "Beyond the fiction of federalism: Macroeconomic management in multitiered systems." World Politics 54(4):494-531.

Sambanis, Nicholas and Branko Milanovic. 2014. “Explaining Regional Autonomy Differences in Decentralized Countries." Comparative Political Studies 47(13):1830-1855.

Scharpf, Fritz W. 1988. "The joint decision trap: Lessons from German federalism and European integration." Public Administration 66(3):239-278.

Scharpf, Fritz W. 1997. Games Real Actors Play: Actor-Centered Institutionalism in Policy Research. Boulder: Westview Press.

Schelling, Thomas C. 1980. The strategy of conflict. Harvard University Press.

Simon Cosano, Pablo. 2020. “The Multiple Spanish Elections of April and May 2019: The Impact of Territorial and Left-right Polarisation." South European Society and Politics . 
Sinnot. 2006. "An evaluation of the measurement of national, subnational and supranational identity in crossnational surveys." International Journal of Public Opinion Research 18(2):211-223.

Stepan, Alfred C. 1999. "Federalism and democracy: Beyond the US model." Journal of Democracy 10(4):19-34.

Swenden, Wilfried and Bart Maddens. 2009. Territorial party politics in Western Europe. Springer.

Tilley, James and Sara B Hobolt. 2011. "Is the Government to Blame? An Experimental Test of How Partisanship Shapes Perceptions of Performance and Responsibility." The Journal of Politics 73(2):115.

Tocqueville, Alexis de. 1835. Democracy in America. Saunders and Otley (London).

Toubeau, Simon and Markus Wagner. 2015. “Explaining party positions on decentralization.” British Journal of Political Science 45(1):97-119.

Turnbull-Dugarte, Stuart J. 2019. “Explaining the end of Spanish exceptionalism and electoral support for Vox." Research \& Politics 6(2):1-8.

Van Huyck, John B, Raymond C Battalio and Richard O Beil. 1990. “Tacit coordination games, strategic uncertainty, and coordination failure." The American Economic Review 80(1):234-248.

Van Huyck, John B, Raymond C Battalio and Richard O Beil. 1991. "Strategic uncertainty, equilibrium selection, and coordination failure in average opinion games." The Quarterly Journal of Economics 106(3):885-910.

Vidal, Guillem. 2018. “Challenging business as usual? The rise of new parties in Spain in times of crisis." West European Politics 41(2):261-286.

Wheare, Kenneth Clinton. 1946. Federal government/KC Wheare. London; New York: H. Milford; Oxford University Press, 1946.

Wibbels, Erik. 2005. Federalism and the market: Intergovernmental conflict and economic reform in the developing world. Cambridge University Press.

Ziblatt, Daniel. 2006. Structuring the state: The formation of Italy and Germany and the puzzle of federalism. Princeton University Press. 